Oropharyngeal dysphagia is a major complaint among many patients suffering from neurological diseases as well as in the elderly. Its severity ranges from moderate difficulty to complete inability to swallow, and it may give rise to clinically relevant complications such as aspiration pneumonia, malnutrition and/or dehydration, impaired quality of life, and death. However, despite its high prevalence and even though it would be very cost-effective to avoid complications by adequate treatment, dysphagia is still severely underdiagnosed.

The contributions in this book present and discuss state-of-the-art diagnostic methods, treatment, and care of dysphagia patients, putting special emphasis on a multidisciplinary approach. A variety of clinical specialists will find this publication a most valuable addition to their library, including nurses, speech-language pathologists, dieticians, nutritionists, gastroenterologists and related specialties.

Nestlé Nutrition Institute Workshop Series, Vol. 72 ISSN 1664-2147 / e-ISSN 1664-2155

Stepping Stones to Living Well with Dysphagia

Editors: Cichero, J. (Brisbane, QLD);

Clavé, P. (Barcelona)

XVI + 138 p., 17 fig., 19 tab., hard cover, 2012

CHF 50.- / EUR 42.- / USD 59.00

Prices subject to change

EUR price for Germany, USD price for USA only

ISBN 978-3-318-02113-4

e-ISBN 978-3-318-02114-1

Fields of Interest: Nutrition; Otorhinolaryngology; Gerontology; Gastroenterology

\section{www.karger.com/nniws}

Nestlé Nutrition Institute Workshop Series, Vol. 72

\title{
Stepping Stones to Living Well with Dysphagia
}

Editors

\section{Julie Cichero \\ Pere Clavé}

\section{Contents}

Preface

Foreword

Contributors

\section{Introduction}

Definition, Prevalence and Burden of

Oropharyngeal Dysphagia: A Serious Problem among Older Adults Worldwide and the Impact on Prognosis and Hospital Resources: Cichero, J.A.Y.; Altman, K.W.

The Physiology of Deglutition and the Pathophysiology and Complications of Oropharyngeal Dysphagia: Steele, C.M.

\section{Detection}

Identifying Vulnerable Patients: Role of the EAT-10 and the Multidisciplinary Team for Early Intervention and Comprehensive Dysphagia Care: Kaspar, K.; Ekberg, O.

The Volume-Viscosity Swallow Test for Clinical Screening of Dysphagia and Aspiration:

Rofes, L.; Arreola, V.; Clavé, P.

Videofluoroscopic Swallow Study: Techniques, Signs and Reports: Bülow, M.

Screening and Clinical Assessment of Oropharyngeal Dysphagia: Martino, $R$.

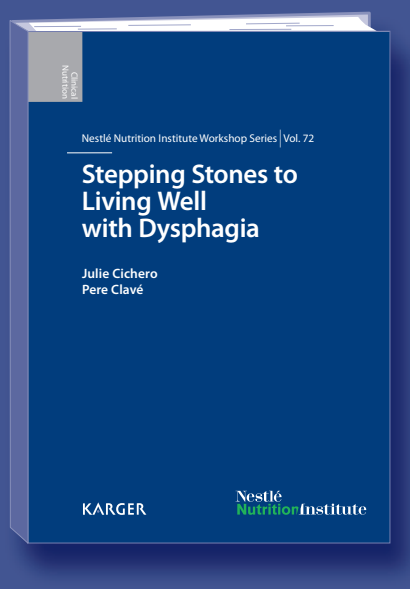

Dysfunction and Related Complications

Pathophysiology, Relevance and Natural History of Oropharyngeal Dysphagia among Older People: Clavé, P.; Rofes, L.; Carrión, S.; Ortega, O.; Cabré, M.; Serra-Prat, M.; Arreola, V. Complications of Oropharyngeal Dysphagia: Aspiration Pneumonia: Almirall, J.; Cabré, M.; Clavé, $P$

Nutrition Assessment and Intervention in the Patient with Dysphagia: Challenges for Quality Improvement: Ochoa, J.B.

\section{Interventions}

Therapeutic Approach to Malnutrition and Sarcopenia: Burgos Peláez, $R$.

Importance of Nutritional Support in Older People: Sánchez García, E.;

Montero Errasquín, B.; Sánchez Castellano, C.; Cruz-Jentoft, A.J.

Exercise-Based Approaches to Dysphagia Rehabilitation: Steele, C.M.

Oropharyngeal Dysphagia Pathophysiology, Complications and Science-Based Interventions: Altman, K.W. 


\section{Order Form}

\section{Nestlé Nutrition Institute Workshop Series}

\section{Nestlé Nutrition Institute Workshop Series}

\section{Please send}

ISSN 1664-2147

e-ISSN 1664-2155

In 2011, the two book series 'Nestlé Nutrition Workshop Series: Pediatric Program' and 'Nestlé Nutrition Workshop Series: Clinical \& Performance Program' have been merged to form the 'Nestlé Nutrition Institute Workshop Series'. One of the major components of this series is the organization of workshops and the publication of the proceedings. Each workshop focuses on the latest findings, the controversies and further research needs concerning various topics in nutrition.

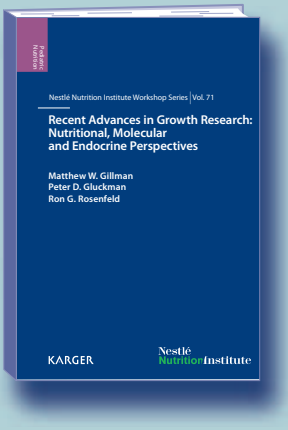

\section{Vol. 71}

Recent Advances in Growth Research: Nutritional, Molecular and Endocrine Perspectives

Editors: Gillman, M.W. (Boston, MA);

Gluckman, P.D. (Auckland); Rosenfeld, R.G. (Los Altos, CA)

Approx. 200 p., 30 fig., 15 tab., hard cover, 2013

CHF 50.- / EUR 42.- / USD 59.00

ISBN 987-3-318-02269-8

e-ISBN 987-3-318-02270-4

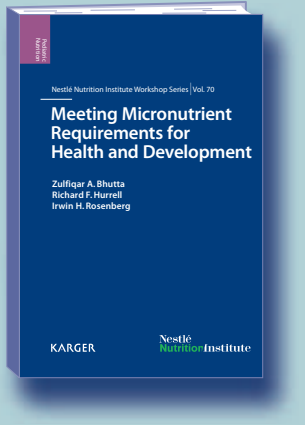

\section{Vol. 70}

Meeting Micronutrient Requirements

for Health and Development

Editors: Bhutta, Z.A. (Karachi); Hurrell, R.F. (Zurich);

Rosenberg I.W. (Boston, MA)

XVIII + 194 p., 24 fig., 16 tab., hard cover, 2012

CHF 50.- / EUR 42.- / USD 59.00

ISBN 978-3-318-02111-0

e-ISBN 978-3-318-02112-7

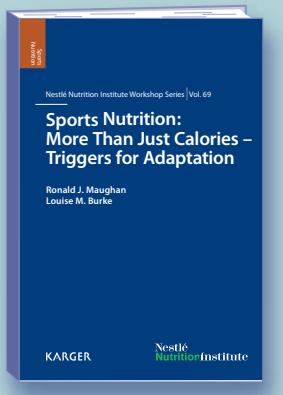

Vol. 69

Sports Nutrition: More than Just Calories -

Triggers for Adaptation

Editors: Maughan, R.J. (Loughborough); Burke, L.M. (Bruce)

XIV + 154 p., 14 fig., 2 tab., hard cover, 2011

CHF 50.- / EUR 42.- / USD 59.00

ISBN 978-3-8055-9697-8

e-ISBN 978-3-8055-9698-5

\section{www.karger.com/nniws}

copy/ies: Vol. 72: Stepping Stones to

Living Well with Dysphagia

CHF 50.- / EUR 42.- / USD 59.00

ISBN 978-3-318-02113-4

e-ISBN 978-3-318-02114-1

_ copy/ies

ISBN 978-3-318-

the book series Nestlé Nutrition Institute Workshop Series on continuation beginning with vol.

All Karger series are available on continuation. Each volume will be sent upon publication until order is countermanded.

Postage and handling free with prepayment

For easy ordering or further information about the series log on to: www.karger.com/nniws

Payment

$\bigcirc$ Please charge to my credit card

$\bigcirc$ American Express $\bigcirc$ Diners

$\bigcirc$ Eurocard $\bigcirc$ MasterCard $\bigcirc$ visa

Card No.

Exp. date:

$\bigcirc$ Check enclosed $\bigcirc$ Please bill me

Name/Address:

Date:

Signature:

Orders can be placed at agencies, bookstores, directly with the publisher, or with any Karger distributor.

S. Karger AG, P.O. Box, 4009 Basel (Switzerland) Fax +41 6130612 34, E-Mail orders@karger.ch

USA: S. Karger Publishers, Inc., 26 West Avon Road,

P.O. Box 529, Unionville, CT 06085 (USA),

Toll free: 1-800-828-5479

Germany: S. Karger GmbH, 79098 Freiburg

France: Librairie Médi-Sciences, 75007 Paris

Gulf Council Countries, Iran, Middle East,

North Africa, Turkey: Trans Middle East Internat.

Distribution Co. Ltd., KaSha, Amman 11953 (Jordan)

Japan: Karger Japan, Inc., Tokyo 105-0012

South East Asia, China and Taiwan:

Karger Regional Office, Kuala Lumpur 50470 (Malaysia)

For details and further representatives and agencies see www.karger.com/worldwide 